\title{
PEMAHAMAN KONSEP SUHU DAN KALOR MAHASISWA CALON GURU
}

\author{
Muhammad Reyza Arief Taqwa ${ }^{1}$ \\ Rian Priyadi ${ }^{2}$ \\ Lugy Rivaldo ${ }^{3}$
}

Program Studi Pendidikan Fisika, FMIPA, Universitas Negeri Malang ${ }^{1}$ Magister Pendidikan Fisika, Pascasarjana, Universitas Negeri Malang ${ }^{2}$ Program Studi Pendidikan Fisika, FKIP, Universitas Jambi ${ }^{3}$

Email: reyza.arief.fmipa@um.ac.id

\begin{abstract}
Abstrak
Penelitian ini bertujuan untuk mendeskripsikan pemahaman konsep mahasiswa pendidikan fisika dalam memahami konsep kalor. Penelitian dilakukan pada mahasiswa S1 pendidikan fisika (37 mahasiswa tahun pertama, 21 mahasiswa tahun kedua, dan 14 mahasiswa tahun ketiga) dan 24 mahasiswa S2 pendidikan fisika. Data yang diungkap difokuskan pada pemahaman konsep kalor jenis dan kapasitas kalor. Hasil analisis menunjukkan bahwa mahasiswa masih mengalami kekeliruan dalam memahami beberapa konsep, diantaranya (1) menyatakan bahwa kalor jenis dipengaruhi oleh massa, kalor dan perubahan suhu, (2) memaknai kalor jenis besar sebagai benda yang mudah mengalami kenaikan suhu, dan (3) menyatakan bahwa kapasitas kalor dipengaruhi oleh kalor dan kenaikan suhu.
\end{abstract}

Kata Kuci:Pemahaman konsep, suhu dan kalor.

\begin{abstract}
This study aims to describe the heat conceptual understanding of physics education students. The research was conducted on physics education S1 students (37 1st year students', 21 2nd year students', and 14 3th year students') and 24 students of physics education. The data revealed focuson the understanding of specific heat and heat capacity. The results of the analysis indicate that the students are still experiencing errors in understanding some concepts, including (1) stating that the heat of the type is influenced by mass, heat and temperature changes, (2) interpreting large-scale heat as objects that easily increase temperature, and (3) That the heat capacity is affected by the heat and temperature rise.
\end{abstract}

Keywords :Conceptual understanding, temperature and heat. 


\section{PENDAHULUAN}

Hasil penelitian menunjukkan bahwa kekeliruan pemahaman konsep fisika merupakan salah satu hal yang sulit diubah oleh siswa (McDermott, 2001; Berek, et al., 2016). Konsep suhu dan kalor sangat penting di dalam fisika karena terkait penerapannya dalam bidang sains dan teknologi (Kulkarni \& Tambade, 2013). Kendati demikian, masih banyak ditemui kesulitan siswa dalam memahami konsep tersebut.

Beberapa kesulitan yang telah diungkap diantaranya dalam memahami entropi terkait hukum II termodinamika (Meltzer, 2004; Yeo \& Zadnik, 2001). Selain itu, banyak siswa mengalami kesulitan dalam memahami konsep kalor, suhu, dan energi dalam (Kulkarni \& Tambade, 2013). Kesulitan terkait topik suhu dan kalor ini sendiri telah ditemukan pada siswa jenjang SMP maupun SMA, bahkan jenjang perguruan tinggi. Setyadi\& Komalasari (2012) menemukan bahwa dari 50 siswa SMA kelas 1 terdapat $63,7 \%$ siswa mengalami miskonsepsi pada topik suhu dan kalor sehingga terkendala dalam memahami konsep. Bahkan miskonsepsi yang dialami pada kriteria tinggi. Pada siswa SMP, $70,7 \%$ mahasiswa mengalami miskonsepsi tentang pengaruh kalor dalam perubahan suhu suatu zat sebelum dilaksanakan pembelajaran. Setelah pembelajaran, 51,2\% mahasiswa ternyata masih mengalami miskonsepsi terkait konsep tersebut (Iriyanti, et al., 2012). Hal ini menunjukkan bahwa miskonsepsi yang dialami siswa bersifat retensi sehingga sulit diubah (Taqwa \& Pilendia, 2018), sehingga penting merancang pembelajaran yang memfasilitasi mahasiswa untuk mampu mengalami perubahan konsep (Taqwa, et al., 2017). Meskipun beberapa penelitian telah mengungkap kesulitan dalam topik suhu dan kalor, namun identifikasi kesulitan ini masih perlu dilakukan mengingat kesulitan mahasiswa ataupun siswa sangat beragam. Kesulitan tersebut penting untuk diidentifikasi sebelum kegiatan pembelajaran agar pengajar lebih baik dalam merancang kegiatan pembelajaran (Taqwa, 2017; Rivaldo et al., 2018). Karena dalam penelitian 
ini akan diungkap kekeliruan siswa

dalam memahami konsep kalor.

\section{METODE}

$\begin{array}{ccr}\text { Penelitian } & \text { yang } & \text { dilakukan } \\ \text { merupakan } & \text { penelitian } & \text { dengan } \\ \text { menggunakan } & \text { metode } & \text { survey. }\end{array}$

Penelitian dilakukan pada mahasiswa

calon guru Fisika di Universitas

Negeri Malang, baik pada

mahasiswa S1 maupun S2. Pada

mahasiswa $\mathrm{S} 1$ penelitian dilakukan

pada 37 mahasiswa semester 2, 21

mahasiswa semester 4, dan 14 mahasiswa semester 6, sedangkan pada mahasiswa $\mathrm{S} 2$ penelitian dilakukan pada 24 mahasiswa semester 2 .

Penelitian ini bertujuan untuk mengungkap pemahaman mahasiswa calon guru dalam memahami konsep dasar kalor. Untuk mencapai tujuan pembelajaran tersebut digunakan soal pilihan ganda beralasan. Soal terdiri atas 3 soal konseptual. Berikut ini adalah ketiga soal yang digunakan dalam penelitian ini:
Nomor 1

Suatu benda bermassa $\mathrm{m}$ dipanaskan hingga mengalami kenaikan suhu $\Delta \mathrm{T}$. Kalor yang diberikan pada benda diketahui sebesar Q. Faktor-faktor yang mempengaruhi kalor jenis benda adalah...

A. Massa

B. Kalor yang diberikan

C. Kenaikan suhu

D. Jenis benda

E. Opsi (A), (B), dan (C) benar

F. Opsi (A), (B), (C) dan (D) benar

\section{Alasan:}

Nomor 3

Kapasitas kalor zat $(C)$ didefinisikan sebagai kalor (Q) yang diperlukan untuk menaikkan suhu zat sebesar $1 \mathrm{~K}$. Pernyataan berikut yang benar terkait kapasitas kalor adalah...

A. Semakin banyak kalor yang diberikan maka akan semakin besar $C$ zat

B. Semakin besar kenaikan suhu zat maka akan semakin besar $C$ zat

C. Semakin banyak kalor yang diberikan maka akan semakin $\underline{\text { kecill } C}$ zat

D. Semakin besar kenaikan suhu zat maka akan semakin kecil $C$ zat

E. Jawaban A dan D benar

F. Jawaban A dan $\mathrm{C}$ benar

G. Tidak ada jawaban yang benar $C$ hanya dipengaruhi massa dan jenis benda

\section{Nomor 2}

Benda A memiliki kalor jenis $\mathrm{X} \mathrm{kal} / \mathrm{g}^{\circ} \mathrm{C}$ dan benda $\mathrm{B}$ memiliki kalor jenis $\mathrm{Y} \mathrm{kal} / \mathrm{g}^{\circ} \mathrm{C}$. Kedua benda memiliki massa sama, namun volume benda $\mathrm{A}<$ benda B. Dengan $\mathrm{X}>\mathrm{Y}$, jika kedua benda menyerap kalor yang sama besar maka benda yang mengalami kenaikan suhu lebih tinggi adalah...

A. Benda A

B. Benda B

C. Kedua benda mengalami kenaikan suhu sama

D. Tidak dapat ditentukan, bergantung pada faktor lain

Alasan:

Gambar 1. Soal Konseptual untuk Memahami Konsep Kalor Jenis dan Kapasitas Kalor 
M, R, A, Taqwa., R, Priyadi., L,Rivaldo.- Pemahaman Konsep Suhu ...

Tabel 1. Analisis Kualitas Butir Soal

\begin{tabular}{ccccc}
\hline \multirow{2}{*}{ No } & \multicolumn{2}{c}{ Validitas* } & \multicolumn{2}{c}{ Reliabilitas } \\
\cline { 2 - 3 } & $r_{\text {hitung }}$ & Ket. & Cronbachs' Alpha & Ket. \\
\hline 1 & 0,495 & Valid & & \\
\hline 2 & 0,580 & Valid & 0,871 & Reliabel \\
\hline 3 & 0,508 & Valid & & \\
$* r_{\text {tabel }}=0,2422$ pada taraf signifikansi $0,01$. &
\end{tabular}

Soal tersebut merupakan soal yang telah layak. Berdasarkan hasil analisis validitas, daya beda dan tingkat kesukaran soal yang disajikan pada Tabel 1

Ketiga soal yang dibahas merupakan soal bagian dari soal tes yang valid pada taraf signifikansi 0,01 , karena nilai $r>$ rtabel. Sedangkan untuk tingkat keandalan instrumen dilihat dari nilai Cronbach's Alpha yang bernilai 0 sampai 1(Iacobucci, 2001; Sijtsma, 2009; Taber, 2017; Tavakol \& Dennick, 2011; Warrens, 2014; Yurdugül, 2008). Instrumen layak digunakan jika nilai Cronbach's Alpha setidaknya 0,70(Taqwa, et al., 2017). Hasil analisis pada instrumen soal yang digunakan dalam penelitian menunjukkan bahwa instrumen soal merupakan instrumen yang andal dengan nilai Cronbach's Alpha = 0,871 (Hair, et al., 2010).

Data yang diperoleh dalam penelitian ini berupa data kualitatif dan kuantitatif. Data kuantitatif berupa skor yang diperoleh mahasiswa dalam menjawab soal, sedangkan data kuantitaf diperoleh dari alasan yang diberikan oleh mahasiswa. Data kuantitatif dari skor mahasiswa disajikan dalam tabel yang menginformasikan rata-rata skor mahasiswa untuk tiap butir soal. Alasan yang diberikan mahasiswa dikelompokkan sesuai dengan pemikiran serupa. Alasan yang diberikan oleh mahasiswa ini berguna untuk menggali pemikiran yang dialami dalam menjawab soal.

\section{HASIL DAN PEMBAHASAN}

Jumlah Mahasiswa yang Memilih

\section{Opsi Benar}

Pemahaman konsep mahasiswa terkait konsep kalor masih cenderung rendah. Data perolehan skor pemahaman konsep mahasiswa seperti yang ditunjukkan Tabel 2. 
M, R, A, Taqwa., R, Priyadi., L,Rivaldo.- Pemahaman Konsep Suhu ...

Tabel 2. Jumlah Mahasiswa yang Memilih Opsi Benar

\begin{tabular}{lcccc}
\hline \multirow{2}{*}{ No. Soal } & \multicolumn{3}{c}{ Mahasiswa S1 } & Mahasiswa \\
\cline { 2 - 4 } & Tahun 1 & Tahun 2 & Tahun 3 & S2 \\
\hline 1 & $4(10,81 \%)$ & $4(19,05 \%)$ & $3(21,43 \%)$ & $9(37,50 \%)$ \\
\hline 2 & $7(18,91 \%)$ & $3(14,29 \%)$ & $3(21,43 \%)$ & $15(62,50 \%)$ \\
\hline 3 & $15(40,54 \%)$ & $4(19,05 \%)$ & $2(14,29 \%)$ & $9(37,50 \%)$ \\
\hline Rata-rata & $23,42 \%$ & $17,46 \%$ & $19,05 \%$ & $45,83 \%$ \\
\hline \multicolumn{2}{c}{ Rata-rata total } & \multicolumn{3}{c}{$26,44 \%$} \\
\hline
\end{tabular}

Skor pemahaman konsep mahasiswa dalam menjawab soal konseptual yang mendasar masih cenderung rendah. Hal tersebut diindikasi dari rata-rata skor mahasiswa yang hanya mencapai ratarata total 26,44 (rata-rata total adalah rata-rata dari seluruh nilai rata-rata skor mahasiswa pada tiap kelompok).

Berdasarkan hasil temuan menunjukkan bahwa pemahaman mahasiswa pada topik suhu dan kalor, terutama dalam memahami makna fisis kalor jenis, dan kapasitas kalor masih rendah. Hal tersebut diindikasi dari jumlah mahasiswa yang memilih opsi benar dalam menjawab soal. Kekeliruan ini umum terjadi karena banyak konsep fisika yang abstrak (Fauzi \& Radiyono, 2013; Fikri, Wiyanto, \& Susilo, 2012; Istyowati, Kusairi, \& Handayanto, 2017; Justica, Azrau, \& Suryanda, 2015; kaniawati,
2017), termasuk konsep kalor yang tidak dapat diamati secara langsung. Pemahaman konsep yang abstrak ini memerlukan proses berpikir tingkat tinggi. Dalam proses pembelajaran memerlukan media pembelajaran untuk memvisualisasikan konsep abstrak (Fauzi \& Radiyono, 2013; Hanna, et al., 2016).

Kesalahan siswa dalam memahami konsep suhu dan kalor juga dapat diindikasikan dari distribusi jawaban mahasiswa pada setiap soal. Dominan mahasiswa memilih jawaban yang kurang tepat pada setiap butir soal. Hal ini menunjukkan masih banyaknya kesalahan yang dialami oleh mahasiswa calon guru dalam memahami konsep suhu dan kalor.

Distribusi Pilihan Opsi Jawaban Mahasiswa Soal Nomor 1

Distribusi jawaban mahasiswa pada soal nomor 1 disajikan padaTabel 3. 
M, R, A, Taqwa., R, Priyadi., L,Rivaldo.- Pemahaman Konsep Suhu ...

Tabel 3. Jumlah jawaban mahasiswa pada soal nomor 1

\begin{tabular}{ccccc}
\hline Opsi & \multicolumn{3}{c}{ Mahasiswa S1 } & Mahasiswa \\
\cline { 2 - 4 } Jawaban & Tahun I & Tahun II & Tahun III & S2 \\
\hline A & $1(2,70 \%)$ & $0(0,00 \%)$ & $0(0,00 \%)$ & $0(0,00 \%)$ \\
\hline B & $3(8,11 \%)$ & $0(0,00 \%)$ & $0(0,00 \%)$ & $0(0,00 \%)$ \\
\hline C & $0(0,00 \%)$ & $0(0,00 \%)$ & $0(0,00 \%)$ & $0(0,00 \%)$ \\
\hline$D^{*}$ & $4(10,81 \%)$ & $4(19,05 \%)$ & $3(21,43 \%)$ & $9(37,50 \%)$ \\
\hline E & $20(54,05 \%)$ & $7(33,33 \%)$ & $1(7,14 \%)$ & $2(8,33 \%)$ \\
\hline F & $9(24,32 \%)$ & $10(47,62 \%)$ & $10(71,43 \%)$ & $13(54,17 \%)$ \\
\hline
\end{tabular}

Pada soal nomor 1 mahasiswa diminta untuk menyebutkan faktorfaktor yang mempengaruhi kalor jenis benda. Berdasarkan pilihan opsi jawaban mahasiswa dalam memilih opsi jawaban (ditunjukkan Tabel 3) mengindikasi bahwa mahasiswa masih banyak belum memahami konsep kalor jenis dengan benar.

Pada soal nomor 1, mahasiswa yang memilih opsi $\mathrm{E}$ dan $\mathrm{F}$ berpikir bahwa kalor jenis dipengaruhi oleh besaran-besaran fisis berdasarkan persamaan $\mathrm{c}=\mathrm{Q} / \mathrm{m} \Delta \mathrm{T}$. Sehingga berdasarkan persamaan tersebut, mahasiswa yang memilih opsi E dan F berpikir bahwa kalor jenis dipengaruhi oleh kuantitas kalor $(\mathrm{Q})$, massa $(\mathrm{m})$, dan perubahan suhu $(\Delta \mathrm{T})$. Hal tersebut menunjukkan bahwa mahasiswa hanya menginat rumus tanpa memahami makna fisisnya dalam mempelajari fisika (Hanna et al., 2016; Hasnawiyah, et al., 2013; Ismiazizah, et al., 2017). Mahasiswa lebih beriorientasi pada rumus fisika, sehingga mengganggap bahwa pelajaran fisika terlalu banyak rumus solah-olah pelajaran fisika hanya kumpulan rumus-rumus. Temuan tersebut didukung hasil survey Azizah, et al (2015) yang menemukan sebanyak $71 \%$ siswa (dari total 120 siswa yakni dari SMA Negeri 1 Bangil, SMA Negeri 8 Malang, dan SMA Yadika Bangil) menyatakan bahwa fisika merupakan pelalajaran yang sulit karena terlalu banyak rumus. Selain itu, ada banyak faktor lain yang mempengaruhi kemampuan siswa dalam memahami konsep fisika, seperti gaya belajar (Taqwa, et al., 2015) dan sebagainya.

Distribusi Pilihan Opsi Jawaban Mahasiswa Soal Nomor 2 
Pada soal nomor 2 mahasiswa diminta untuk membandingkan besar kenaikan suhu pada dua benda dengan kalor jenis berbeda namun memiliki massa sama. Tabel 4 menunjukkan distribusi pilihan opsi jawaban mahasiswa dalam menjawab soal nomor 2 .

Tabel 4.Persentase pilihan opsi jawaban mahasiswa pada soal nomor 2

\begin{tabular}{ccccc}
\hline \multirow{2}{*}{$\begin{array}{c}\text { Opsi } \\
\text { Jawaban }\end{array}$} & \multicolumn{3}{c}{ Mahasiswa S1 } & Mahasiswa \\
\cline { 2 - 5 } & Tahun I & $\begin{array}{c}\text { Tahun } \\
\text { II }\end{array}$ & Tahun III & S2 \\
\hline A & $15(40,54 \%)$ & $9(42,86 \%)$ & $9(64,29 \%)$ & $6(25,00 \%)$ \\
\hline B* & $7(18,91 \%)$ & $3(14,29 \%)$ & $3(21,43 \%)$ & $15(62,50 \%)$ \\
\hline C & $15(40,54 \%)$ & $9(42,86 \%)$ & $2(14,29 \%)$ & $3(12,50 \%)$ \\
\hline D & $0(0,00 \%)$ & $0(0,00 \%)$ & $0(0,00 \%)$ & $0(0,00 \%)$ \\
\hline
\end{tabular}

Dalam menjawab soal tersebut bahwa mahasiswa belum memaknai banyak mahasiswa yang memilih opsi A. Mahasiswa yang memilih opsi A konsep kalor jenis dengan baik. berpikir bahwa benda dengan kalor jenis besar akan mudah mengalami Beberapa mahasiswa diantaranya menggunakan persamaan kalor jenis namun keliru dalam melihat kenaikan suhu. Hal ini menunjukkan hubungan variabel (lihat Gambar 2).

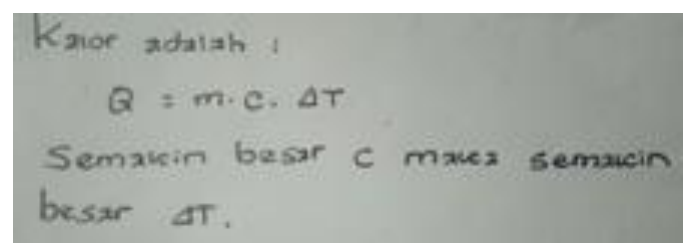

Gambar 2. Alasan Mahasiswa yang memilih opsi A

Berdasarkan alasan tersebut dapat dilihat bahwa sebenarnya mahasiswa mengingat persamaan kalor dengan benar. Hanya saja keliru dalam melihat perbandingan antara variabel kalor jenis (c) dan perubahan suhu $(\Delta \mathrm{T})$. Mahasiswa yang memilih opsi
A berpikir bahwa kenaikan suhu benda (bermassa sama) yang menyerap kalor sama besar adalah berbanding lurus dengan kalor jenis (c).

Hasil tersebut menunjukkan bahwa dalam memahami makna fisis pada 
suatu persamaan diperlukan kemampuan matematis. Dalam fisika perlu memahami persamaan matematis, mendeskripsikan bagaimana hubungan antar variabel secara benar. Meskipun sebenarnya persamaan matematis dibangun sebagai pemodelan dan mendeskripsikan kondisi fisis, namun tak jarang mahasiswa hanya mengenal persamaan matematis tanpa mampu memahami makna secara komprehensif untuk menjelaskan gambaran fisisnya (Priyadi et al., 2018). Kemampuan matematika yang baik diperlukan dalam belajar fisika, karena dengan kemampuan matematika yang baik akan membantu dalam memecahkan persoalan fisika (Haryadi, 2016; Nurdin, 2017; Nurlailiyah \& Deta,
2015). Bahkan sebenarnya kegagalan mahasiswa dalam memecahkan masalah bukan karena tidak memeiliki pengetahuan, melainkan gagal dalam mengaktivasi pengetahuan yang ia miliki (Rivaldo, et al., 2018). Oleh karena itu, pemahaman fisika yang baik dan kemampuan matematis yang memadai harus dimiliki secara utuh oleh mahasiswa.

\section{Distribusi Pilihan Opsi Jawaban}

\section{Mahasiswa Soal Nomor 3}

Pada soal nomor 3 mahasiswa diminta untuk menentukan faktor yang mempengaruhi kapasitas kalor. Dalalm soal tersebut diberikan definisi kapasitas kalor. Distribusi pilihan opsi jawaban mahasiswa dalam menjawab soal nomor 3 ditunjukkan Tabel 5.

Tabel 5. Persentase pilihan opsi jawaban mahasiswa pada soal nomor 3

\begin{tabular}{ccccc}
\hline \multirow{2}{*}{$\begin{array}{c}\text { Opsi } \\
\text { Jawaban }\end{array}$} & Tahun I & Tahun II & Tahun III & \multirow{2}{*}{ Mahasiswa S2 } \\
\cline { 2 - 5 } A & $0(0,00 \%)$ & $0(0,00 \%)$ & $0(0,00 \%)$ & $0(0,00 \%)$ \\
\hline B & $0(0,00 \%)$ & $0(0,00 \%)$ & $0(0,00 \%)$ & $0(0,00 \%)$ \\
\hline C & $0(0,00 \%)$ & $0(0,00 \%)$ & $0(0,00 \%)$ & $0(0,00 \%)$ \\
\hline D & $0(0,00 \%)$ & $0(0,00 \%)$ & $0(0,00 \%)$ & $0(0,00 \%)$ \\
\hline E & $22(59,46 \%)$ & $17(80,95 \%)$ & $12(85,71 \%)$ & $15(62,50 \%)$ \\
\hline F & $0(0,00 \%)$ & $0(0,00 \%)$ & $0(0,00 \%)$ & $0(0,00 \%)$ \\
\hline G* & $15(40,54 \%)$ & $4(19,05 \%)$ & $2(14,29 \%)$ & $9(37,50 \%)$ \\
\hline
\end{tabular}


M, R, A, Taqwa., R, Priyadi., L,Rivaldo.- Pemahaman Konsep Suhu ...

Kesulitan mahasiswa dalam mahasiswa yang keliru dalam

menjawab soal nomor 3 tidak jauh berbeda dengan soal nomor 1. Dalam menjawab soal tersebut sebagian besar mahasiswa keliru dan dengan kesalahan yang sama, yakni memilih opsi E baik mahasiswa S1 maupun mahasiswa S2. Pada mahasiswa S1 sebanyak $22 \quad(59,46 \%)$ mahasiswa tahun pertama, $17 \quad(80,95 \%)$ mahasiswa tahun kedua, dan 12 $(85,71 \%)$ mahasiswa tahun ketiga, dan pada mahasiswa S2 sebanyak 15 $(62,50 \%)$ mahasiswa yang mengalami kekeliruan. Opsi E menunjukkan bahwa mahasiswa mengingat persamaan $C=Q / \Delta T, \quad$ sehingga mereka berpikir bahwa besarnya kapasitas kalor sebanding dengan $Q$ dan berbanding terbalik dengan $\Delta T$. Temuan ini juga mengindikasikan bahwa kecenderungan mahasiswa adalah menyelesaikan soal dengan menggunakan rumus yang diingat tanpa memverifikasi kebenaran rumus (Hamidah, et al., 2015).

\section{PENUTUP}

\section{Kesimpulan}

Berdasarkan hasil yang diperoleh dapat disimpulkan bahwa banyak

memahami konsep kalor jenis dan kapasitas kalor dengan benar. Pertama, kekeliruan dalam memahami variabel yang berpengaruh pada kalor jenis. Kekeliruan ini dikarenakan mahasiswa keliru dalam memaknai kalor jenis dari persamaan $c=$ $Q / m \Delta T$. Kedua, kekeliruan dalam membandingkan kenaikan suhu yang dialami dua benda (bermassa sama)ketika menyerap kalor yang sama besar. Salah satu kekeliruan dalam menyelesaikan permasalahan tersebut adalah ketika mahasiswa menggunakan persamaan $Q=m c \Delta T$ menyimpulkan bahwa c berbanding lurus dengan $\Delta T, \quad$ sehingga menganggap bahwa semakin besar kalor jenis benda maka akan cepat mengalami kenaikan suhu. Ketiga, dalam menentukan kapasitas kalor juga mahasiswa mengalami kekeliruan serupa seperti saat menentukan kalor jenis. Mereka menggunakan persamaan matematis $C=Q / \Delta T$ sehingga menyimpulkan bahwa kapasitas kalor benda dipengaruhi oleh kalor dan perubahan suhu. 
M, R, A, Taqwa., R, Priyadi., L,Rivaldo.- Pemahaman Konsep Suhu ...

\section{Saran}

Temuan ini menunjukkan bahwa mahasiswa yang mengalami kekeliruan dalam memahami konsep kalor jenis dan kapasitas kalor beberapa diantaranya disebabkan oleh kekeliruan dalam menginterpretasi makna fisis suatu persamaan. Oleh karena itu, pembelajaran perlu dirancang agar mahasiswa dapat membangun konsep fisis dengan baik. Bagi mahasiswa, diharapkan temuan ini dapat menginspirasi untuk memahami fisika secara lebih baik, tidak hanya memandang fisika sebagai kumpulan rumus saja.

\section{DAFTAR PUSTAKA}

Azizah, R., Yuliati, L., \& Latifah, E. (2015). Kesulitan Pemecahan Masalah Fisika pada Siswa SMA. Jurnal Penelitian Fisika Dan Aplikasinya (JPFA), 5(2), 44-50. DOI:10.26740/jpfa

Berek, F. X., Sutopo, S., \& Munzil, M. (2016). Concept enhancement of junior high school students in hydrostatic pressure and archimedes law by predictobserve-explain strategy. Jurnal Pendidikan IPA Indonesia, 5(2), 230-238.

DOI:10.15294/jpii.v5i2.6038

Fauzi, A., \& Radiyono, Y. (2013). Pengembangan Bahan Ajar Fisika Dasar I Berbasis Spreadsheet dengan Pendekatan Analitik dan
Numerik. Jurnal Materi Dan Pembelajaran Fisika, 1(1), 15-21. Fikri, K., Wiyanto, \& Susilo. (2012). Penerapan Pembelajaran Fisika dengan Analogi untukn Meningkatkan Hasil Belajar Siswa SMA. Unnes Physics Education Journal, 1(2), 1-4.

Hair, J. F., Black, W. C., Babin, B. J., \& Anderson, R. E. (2010). Multivariate Data Analysis (7th ed.). New Jersey: Prentice Hall, Upper Saddle River.

Hamidah, Darmadi, I. W., \& Darsikin. (2015). Analisis Pemahaman Arti Fisis Konsep Newton Mahasiswa Calon Guru. Jurnal Pendidikan Fisika Tadulako, 3(4).

DOI:10.22487/j25805924.2015.v3. i4.5371

Hanna, D., Sutarto, \& Harijianto, A. (2016). Model Pembelajaran Tema Konsep Disertai Media Gambar pada Pembelajaran Fisika Di SMA. Jurnal Pembelajaran Fisika, 5(5), 23-29.

Haryadi, R. (2016). Korelasi Antara Matematika Dasar Dengan Fisika Dasar. Jurnal Penelitian Dan Pembelajaran Matematika, 9(1), 124-127.

DOI:10.30870/JPPM.V9I1.988.G7 89

Hasnawiyah, Wahyono, U., \& Darsikin. (2013). Pemahaman Konsep Hubungan antara Arah Gaya , Kecepatan dan Percepatan dalam Satu Dimensi pada Mahasiswa Calon Guru Fisika FKIP Universitas Tadulako. Jurnal Pendidikan Fisika Tadulako, 1(3), 38-44.

DOI:10.22487/j25805924.2013.v1. i3.2537 
Iacobucci, D. (2001). Measurement. Journal of Consumer Psychology's Special Issue on Methodological and Statistical Concens of the Experimental Behavioral Researcher, 10(1\&2), 55-69. DOI:Mahwah, NJ: Lawrence Erlbaum Associates

Iriyanti, N. P., Mulyani, S., \& Ariani, S. R. D. (2012). Identifikasi Miskonsepsi Pada Materi Pokok Wujud Zat Siswa Kelas Vii Smp Negeri 1 Bawang. Jurnal Pendidikan Kimia, 1(1), 8-13.

Ismiazizah, N., Prihandono, T., \& Harijianto, A. (2017). Pengaruh Model Pembelajaran Generatif Disertai Concept Mapping terhadap Hasil Belajar dan Keterampilan Proses Sains pada Pembelajaran Fisika di SMAN Tempeh. Jurnal Pembelajaran Fisika, 6(4), 383-389.

Istyowati, A., Kusairi, S., \& Handayanto, S. K. (2017). Analisis Pembelajaran dan Kesulitan Siswa SMA Kelas XI terhadap Penguasaan Konsep Fisika. In Seminar Nasional III (pp. 237243). Malang: Universitas Muhammadiyah Malang.

Justica, A. A., Azrau, E. P., \& Suryanda, A. (2015). Pengaruh Penggunaan Model Pembelajaran Analogi dalam Pembelajaran IPA terhadap Kemampuan Berpikir Kreatif Siswa SMP. Biosfer, 8(1), 51-56.

K, E. setyadi, \& Komalasari, A. (2012). Miskonsepsi Tentang Suhu dan Kalor Pada Siswa Kelas 1 Di Sma Muhammadiyah Purworejo, Jawa Tengah. Berkala Fisika Indonesia, 4(1 \& 2), 46-49.

Kaniawati, I. (2017). Pengaruh Simulasi Komputer terhadap
Peningkatan Penguasan Konsep Impuls-Momentum Siswa SMA. Jurnal Pembelajaran Sains, 1(1), 24-26.

Kulkarni, V., \& Tambade, P. (2013). Assessing the Conceptual Understanding about Heat and Thermodynamics at Undergraduate Level. European Journal of Physics Education, 4(2), 9-16. Retrieved from http://ejpe.erciyes.edu.tr/index.php /EJPE/article/view/101

McDermott, L. C. (2001). OerstedMedal Lecture 2001: "Physics Education ResearchThe Key to Student Learning." American Journal of Physics, 69(11), 1127-1137. DOI:10.1119/1.1389280

Meltzer, D. E. (2004). Investigation of students' reasoning regarding heat, work, and the first law of thermodynamics in an introductory calculus-based general physics course. American Journal of Physics, 72(11), 1432-1446. DOI:10.1119/1.1789161

Nurdin, A. N. (2017). Analisis Hubungan Kemampuan Numerik dengan Hasil Belajar Fisika Peserta Didik Kelas XII IPA SMA Muhammadiyah di Makasar. Jurnal Pendidikan Fisika Universitas Muhammadiyah Makassar, 5(2), 193-204.

Nurlailiyah, A., \& Deta, U. A. (2015). Studi korelasi antara kemampuan matematika dengan hasil belajar fisika di sma pgri sumberrejo bojonegoro tahun ajaran 2014/2015. Jurnal Penelitian Fisika Dan Aplikasinya (JPFA), 5(2), 64-69.

Priyadi, R., Mustajab, A., Tatsar, M. Z., \& Kusairi, S. (2018). Analisis 
Kemampuan Berpikir Kritis Siswa SMA Kelas X MIPA dalam Pembelajaran Fisika. Jurnal Pendidikan Fisika Tadulako, 6(1), 53-55.

DOI:10.22487/j25805924.2018.v6. i1.10020

Rivaldo, L., Taqwa, M. R. A., \& Taurusi, T. (2018). Resources Siswa SMA tentang Konsep Gaya Archimedes. Jurnal Pendidikan Fisika Universitas Muhammadiyah Makassar, 6(3), 251-258. Retrieved from http://journal.unismuh.ac.id/index. php/jpf/issue/view/114/showToc

Sijtsma, K. (2009). On the use, the misuse, and the very limited usefulness of cronbach's alpha. Psychometrika, 74(1), 107-120. DOI:10.1007/s11336-008-9101-0

Taber, K. S. (2017). The Use of Cronbach's Alpha When Developing and Reporting Research Instruments in Science Education. Research in Science Education, 1-24. DOI:10.1007/s11165-016-9602-2

Taqwa, M. R. A., Astalini, \& Darmaji. (2015). Hubungan Gaya Belajar Visual, Auditorial, dan Kinestetik dengan Hasil Belajar Siswa pada Materi Dinamika Rotasi dan Kesetimbangan Benda Tegar Kelas XI IPA SMA Se-Kota Jambi. Prosiding Seminar Nasional Sains dan Pendidikan Sains 5, Purwokerto: Univesitas Muhammadiyah Purwokerto.

Taqwa, M. R. A. (2017). Profil Pemahaman Konsep Mahasiswa dalam Menentukan Arah Resultan Gaya. In Prosiding Seminar Nasional Pendidikan Sains (pp. 79-87).
Taqwa, M. R. A., \&Pilendia, D. (2018). Kekliruan Memahami Konsep Gaya, Apakah Pasti Miskonsepsi?. Jurnal Inovasi Pendidikan Fisika dan Integrasinya, 1(1), 1-12.

Taqwa, M. R. A., Hidayat, A., \& Supoto. (2017). Konsistensi Pemahaman Konsep Kecepatan dalam Berbagai Representasi. Jurnal Riset \& Kajian Pendidikan Fisika, 4(1), 31-39. DOI:http://dx.doi.org/10.12928/jrk pf.v4i1.6469

Taqwa, M. R. A., Hidayat, A., \& Sutopo. (2017). Deskripsi Penggunaan Program Resitasi dalam Meningkatkan Kemampuan Membangun Free-Body Diagrams ( FBDs ). Jurnal Pendidikan Fisika Tadulako, 5(1), 52-58. DOI:10.22487/j25805924.2017.v5. i1.8411

Tavakol, M., \& Dennick, R. (2011). Making sense of Cronbach's alpha. International Journal of Medical Education, 2, 53-55. DOI:10.5116/ijme.4dfb.8dfd

Warrens, M. J. (2014). On Cronbach ' $\mathrm{s}$ Alpha as the Mean of All Possible? -Split Alphas. Advance in Statistic, 2014, 5-10.

Yeo, S., \& Zadnik, M. (2001). Introductory thermal concept evaluation: assessing students' understanding. The Physics Teacher, 39(8), 496-504. DOI:10.1119/1.1424603

Yurdugül, H. (2008). Minimum Sample Size for Cronbach'S Coefficient Alpha: a Monte-Carlo Study. H.U. Journal of Education, 35(1999), 397-405. 